\title{
Coconut milk gavage enhanced fecal bile excretion by modulating hepatic Fxr expression but failed to improve fasting serum cholesterol profile in C57BL/6 mice
}

\author{
Hong Kin Wong ${ }^{1}$, Quok Cheong Choo $^{2}$ and Choy Hoong Chew ${ }^{1, *}$ \\ ${ }^{1}$ Department of Allied Health Sciences, Universiti Tunku Abdul Rahman, Faculty of Science, 31900 Kampar, Perak \\ 2 Department of Biological Science, Universiti Tunku Abdul Rahman, Faculty of Science, 31900 Kampar, Perak
}

Received 4 May 2020 - Accepted 14 August 2020

\begin{abstract}
The consumption of coconut milk has long been regarded as detrimental to cardiovascular health due to its high saturated fatty acid content. Contradictorily, emerging evidences have highlighted that the fatty acids in coconut lipids, which comprise mostly of medium-chain fatty acids (MCFA), may be beneficial to the regulation of serum cholesterol. To identify the potential health effect of coconut milk on lipid metabolism, this current study employed an intragastric gavage method on C57BL/6 mice to investigate the physiological and molecular alteration in the mice subject after 8 weeks of gavage intervention. The supplementation of coconut milk did not affect the levels of serum triglyceride, but it induced the total serum cholesterol after 2 weeks of treatment. The serum cholesterol level subsequently plateaued, but an increase in bile acid excretion was observed, most likely through the modulation of bile regulating genes, i.e. farnesoid X receptor $(F x r)$ and Cyp7a1. Despite that, the total cholesterol to HDL cholesterol ratio of coconut milk group was comparable to that of the light cream group. In short, coconut milk supplementation promoted cholesterol excretion through the fecal bile route but did not significantly improve the serum cholesterol profile of C57BL/6 mice.
\end{abstract}

Keywords: Coconut milk / C57BL/6 / gavage / cholesterol / Fxr

Résumé - La consommation de lait de coco augmente la sécrétion biliaire en modifiant l'expression génique du récepteur $X$ du farnésoïde (Fxr) du foie chez la souris C57BL/6 sans pour autant modifier la cholestérolémie. En raison de sa teneur élevée en acides gras saturés, la consommation de lait de coco est considérée comme préjudiciable à la santé cardiovasculaire. De façon contradictoire, de nouvelles preuves ont mis en évidence que les acides gras des lipides de la noix de coco, qui sont principalement composés d'acides gras saturés à chaîne moyenne (AGCM), peuvent avoir des effets bénéfiques sur l'homéostasie de la cholestérolémie. Afin d'identifier l'effet potentiel de la consommation de ces lipides sur les principaux paramètres du métabolisme des lipides, des souris C57BL/6 ont reçu pendant 8 semaines du lait de coco par gavage intragastrique. Les principales données recueillies soulignent au niveau sérique que la supplémentation en lait de coco ne modifie pas le niveau de triglycérides, mais accroit celui du cholestérol total dès 2 semaines de traitement. Le taux de cholestérol sérique plafonne ensuite mais le rapport entre le cholestérol total et le cholestérol HDL reste inchangé. Une augmentation de l'excrétion des acides biliaires est observée, très probablement via la modulation de l'expression des gènes régulateurs de la voie biliaire, à savoir le récepteur X du farnésoïde (Fxr) et Cyp7a1. Néanmoins, le rapport entre le cholestérol total et le cholestérol HDL du groupe recevant le lait de coco était comparable à celui du groupe de la crème légère. En résumé, la supplémentation en lait de coco favorise chez la souris C57BL/6 l'excrétion du cholestérol par la voie biliaire fécale mais ne modifie pas de manière significative le profil du cholestérol sérique.

Mots clés : Lait de coco / C57BL/6 / gavage / cholestérol / Fxr

\footnotetext{
*Correspondence: chewch@utar.edu.my
} 


\section{Introduction}

Coconut products are consumed as staple food in many countries in the tropical region (Foale, 2003). Numerous epidemiological studies conducted in these areas had pointed out that there was no direct correlation found between coconut fat consumption and metabolic diseases. The number of cases associated with vascular diseases were sparse in populations that consume traditional diet containing little to no processed foods (Lipoeto et al., 2004; Amarasiri and Dissanayake, 2006; DiBello et al., 2009). Thus, these researchers questioned if the causative role of coconut fat in the pathology of cardiovascular disease had been biased perceived. Nonetheless, such results should be interpreted cautiously since diet may not be the sole contributor to vascular disease. Furthermore, coconut fat may not be the only reason that the native populations are in good health as there are other nutrients in the native's diet. Eyres et al. (2016) raised concern against the consumption of coconut fat together with lipid-laden Western-styled diet.

For the past few decades, coconut fat is generally regarded as an unhealthy food product due to the high amount of saturated fat $(>10 \%)$ found in this food compound. According to the diet-heart hypothesis, the intake of excess saturated fat would, in turn, deteriorate serum cholesterol level, which ultimately leads to the onset of atherosclerosis and other cardiovascular diseases (Ramsden et al., 2016). Past studies with coconut oil further supported the hypothesis by showing that coconut oil elevated serum total cholesterol levels and triggered the formation of an atherosclerotic lesion in in vivo models (Soma et al., 1985; Mangiapane et al., 1999). However, this claim has been rebutted by other studies which proved that the coconut oil used in those studies was hydrogenated - a modification that would strip coconut oil off its original properties (Enig, 1996; Foale, 2003; Amarasiri and Dissanayake, 2006).

The conversion of cholesterol to bile acid in the liver signifies the final step of the reverse cholesterol transport pathway, and fecal bile secretion serves as the major means of disposing surplus cholesterol from the system (Vallim et al., 2013). Patients with coronary artery diseases (CAD) were found to excrete a lesser amount of bile acid when compared to healthy individuals (Charach et al., 2012). This identifies the importance of bile cholesterol clearance to cardiovascular health. Unfortunately, there are limited evidences in literature on the relationship between coconut fat and bile excretion. Several in vivo studies in the 1980s and 1990s which compared the bile acid metabolic effects of different dietary oils showed that coconut oil had no apparent advantage over other oil types in terms of bile flow and biliary cholesterol excretion (Ramesha et al., 1980; Sim et al., 1980; Høstmark et al., 1989). However, these studies once again used hydrogenated coconut oil.

In recent years, studies have shown that mice supplemented with virgin coconut oil registered the highest hepatic and fecal bile acid content as compared to other oil, i.e. copra oil, sunflower oil, or olive oil (Arunima and Rajamohan, 2012). Nonetheless, the molecular link leading to such observation has not been investigated. The main molecular modulator of bile metabolism is a nuclear receptor known as the farnesoid $\mathrm{X}$ receptor (Fxr). This receptor is bile sensitive and is triggered by bile acids (e.g. chenodeoxycolate and deoxycholate) to regulate its own synthesis. Fxr controls the biosynthesis of bile salt by regulating the expression of Cyp7a1 - the rate-limiting enzyme in bile acid synthesis (Chiang, 2009). Activation of FXR will negatively affect the expression of CYP7A1, which consequently represses the formation of bile salt (Chiang, 2009). The shutdown of this process is usually accompanied by the buildup of cholesterol in hepatocytes, and this will impact the plasma cholesterol level.

This study was aimed to investigate the molecular relationship between coconut milk, bile excretion, and serum cholesterol using an in vivo model system, C57BL/6 mice. Coconut milk was chosen as the source of coconut fat since it is used extensively in the South East Asia but it has received lesser attention than coconut oil. Our results show that mice supplemented with coconut milk exhibited the highest fecal bile content as compared to control and light-creamsupplemented mice. Our molecular studies show that the increase in fecal bile excretion is modulated through Fxr and its downstream effector, Cyp7a1. Regrettably, the supplementation of coconut milk to $\mathrm{C} 57 \mathrm{BL} / 6$ mice did not improve the mice's total cholesterol to HDL ratio as compared to negative and light-cream controls after 8 weeks.

\section{Materials and methods}

\subsection{Coconut milk}

A common brand of coconut milk manufactured in Malaysia was used in this investigation. The nutritional content of coconut milk is as listed in Table 1A. Fatty acid analysis on the commercial coconut milk product was carried out based on AOAC official method 996.06 fat (total, saturated, and unsaturated) in foods. The analysis was outsourced and performed by an independent private laboratory in Malaysia. The result of the fatty acid analysis is presented in Table $1 \mathrm{~B}$.

\subsection{C57BL/6 mice housing}

Ethical approval on the handling of mice subject was approved by UTAR Scientific and Ethical Review Committee (SERC) (U/SERC/18/2016). The in vivo experiments were conducted at National Yang-Ming University, Taiwan. The experimental C57BL/6 mice were purchased from the National Laboratory Animal Center (NARLabs, Taiwan). The mice were segregated into different cages upon arrival into 3-4 mice per group. The mice were housed in an animal room with a $12-$ hour light/dark cycle controlled by a timer, with the temperature and humidity maintained at $25^{\circ} \mathrm{C}$ and $55-65 \%$, respectively. The mice were allowed ad libitum access to Rodent Diet 5010 (Oriental Yeast Co Ltd, Japan) and water following Guide for the Care and Use of Laboratory Animals until it reached adulthood.

\subsection{Mice gavage}

The mice were nurtured until the age of 16 weeks before the gavage. In the week before the actual experiment, all mice were gavage fed with $200 \mu \mathrm{l}$ of water (mock) four times 
Table 1A. The nutritional composition of the commercial coconut milk and light whipped cream used in this study.

\begin{tabular}{lcc}
\hline $\begin{array}{l}\text { Dietary } \\
\text { components }\end{array}$ & Commercial coconut milk & $\begin{array}{c}\text { Commercial } \\
\text { light cream }\end{array}$ \\
\hline Protein & Amount per $100 \mathrm{ml}$ \\
Fat & $2.2 \mathrm{~g}$ & $2.8 \mathrm{~g}$ \\
Carbohydrate & $20.6 \mathrm{~g}$ & $18 \mathrm{~g}$ \\
Sodium & $2.8 \mathrm{~g}$ & $3.8 \mathrm{~g}$ \\
Energy & $16 \mathrm{mg}$ & $36 \mathrm{mg}$ \\
& $205 \mathrm{kcal}$ & $189 \mathrm{kcal}$ \\
\hline
\end{tabular}

Table 1B. The major fatty acid contents of the commercial coconut milk.

\begin{tabular}{llrc}
\hline Classification & Fatty Acid & C:D & $\begin{array}{l}\text { Amount } \\
\text { (\% of total) }\end{array}$ \\
\hline \multirow{3}{*}{ MCFA (Saturated) } & Octanoic Acid & $8: 0$ & 7.8 \\
& Decanoic Acid & $10: 0$ & 6.4 \\
& Lauric Acid & $12: 0$ & 49.2 \\
& Myristic Acid & $14: 0$ & 18.2 \\
LCFA (Saturated) & Palmitic Acid & $16: 0$ & 8.5 \\
& Stearic Acid & $18: 0$ & 3.4 \\
LCFA (Unsaturated) & Oleic Acid & $18: 1$ & 5.3 \\
& Linoleic Acid & $18: 2$ & 0.8 \\
\hline
\end{tabular}

${ }^{\mathrm{a}}$ Carbon to double bond ratio.

per day - twice between 0800 and 0900 and repeated between 1600 and 1700 . This was performed to familiarize the mice to the gavage feeding. The mice were later segregated into A - water gavage (control, $n=6$ ), $\mathrm{B}$-coconut milk gavage $(n=8)$, and $\mathrm{C}$-lightly whipped cream gavage $(n=6)$. Water was used as the baseline control for the gavage experiment since light cream (Vermeir, 2010) and coconut milk (Tangsuphoom, 2008) are both oil-in-water emulsions. The mice were supplemented with $200 \mu$ l of their corresponding substances (water, coconut milk, or lightly whipped cream) using $1 \mathrm{ml}$ syringe and gavage needle four times per day in a similar fashion as mentioned above. The mice were weighed weekly and monitored closely after gavage started for any distress or abnormal behaviors. The gavage feeding was given daily for 8 weeks, and no aberrant weight change was observed between the three groups throughout the experiment (data not shown).

The nutritional composition of the commercial light whipped cream used is presented in Table 1A. Light cream was included as a control since this food product shares comparable nutrition profile and calorie contents as coconut milk (Tab. 1C). Saturated fat in dairy products is generally rich in long-chain fatty acid (LCFA), consisting mostly of palmitic acid (C16:0), followed by stearic acid (C18:0) and myristic acid (C14:0) (Jost, 2007), which ideally contrasted the high MCFA content found in coconut milk.

\subsection{Whole blood sampling}

Mice whole blood samples were obtained through the tail snip method once a fortnight. Mice were fasted $6 \mathrm{~h}$ before the sampling procedure. The whole blood sample was left at room temperature for 30 minutes to coagulate and centrifuged at $13000 \mathrm{rpm}, 4^{\circ} \mathrm{C}$ for 30 minutes afterward. The supernatant (serum) was collected and aliquoted to be stored at $-80^{\circ} \mathrm{C}$ until further analysis.

\subsection{FUJI DRI-CHEM serum lipids analysis}

The triglycerides and total cholesterol concentrations of the mice serum were determined using FUJI DRI-CHEM Slide TG-PIII and TCHO-PIII (Fujifilm, Japan), respectively. The analysis was carried out semi-automatically by the DRICHEM 3000 Analyzer (Fujifilm, Japan). Briefly, the serum sample $(10 \mu \mathrm{l})$ was administered to the membrane located in the center of the slide. The slide was then slotted into the incubation chamber (heated to $37^{\circ} \mathrm{C}$ ) of the analyzer for 6 minutes. The final readings of the triglycerides or total cholesterol concentration, calculated automatically by the device based on the absorbance measured, were then printed out.

\subsection{High-density lipoprotein cholesterol (HDL-C) assay}

HDL was separated from other lipoprotein fraction (LDL/ VLDL) in the serum by using Precipitation Buffer provided by the commercial HDL and LDL/VLDL Quantification Colorimetric/Fluorometric Kit (BioVision, USA). To measure the HDL concentration, $5 \mu$ l of samples and a series of cholesterol standards $(1,2,3,4$, and $5 \mu \mathrm{g})$ were added to the 96 -well plate. The addition of assay buffer, reaction mix, and incubation time (60 minutes) was performed as per the instruction manual. Colorimetric measurement was performed using Infinite 200 Multimode Microplate Reader (Tecan, Switzerland) to record the reaction's absorbance at $570 \mathrm{~nm}$ wavelength. The absorbance results were used to calculate the HDL cholesterol concentrations with reference to the linear standard curve. Subsequently, the HDL cholesterol and triglycerides readings were substituted into the Friedewald formula $(\mathrm{LDL}=$ Total cholesterol-HDL - Triglycerides / 5) for the estimation of LDL fraction in the blood (Jakulj et al., 2016).

\subsection{Feces collection, bile acid extraction, and fecal bile acid assay}

Fecal samples were collected into clean $1.5 \mathrm{ml}$ centrifuge tubes during the gavage session over three days. Two sets of samples were collected - the baseline samples were collected at Week 0 ; while the treated samples were collected on Week 8 before euthanasia. The fecal bile acid extraction method used in this project was adapted from Boué et al. (2016). Fecal samples of the same mouse were pooled together and dried through vacuum lyophilization at $-40^{\circ} \mathrm{C}$ using VirTis BenchTop 2K Freeze Dryer (SP Scientific, USA). Then, 
H.K. Wong et al:: OCL 2020, 27, 50

Table 1C. The calorie contents of each macronutrient in $0.8 \mathrm{ml}$ of gavage substance given to the mice per day.

\begin{tabular}{|c|c|c|c|c|c|c|}
\hline Substance & \multicolumn{2}{|l|}{ Water } & \multicolumn{2}{|l|}{ Coconut milk } & \multicolumn{2}{|l|}{ Light cream } \\
\hline Fat & - & - & $0.165(20.6 \%)$ & 1.485 & $0.144(18 \%)$ & 1.296 \\
\hline Protein & - & - & $0.018(2.2 \%)$ & 0.072 & $0.022(2.7 \%)$ & 0.088 \\
\hline Carbohydrate & - & - & $0.022(2.8 \%)$ & 0.088 & $0.030(3.7 \%)$ & 0.120 \\
\hline
\end{tabular}

${ }^{\mathrm{a}}$ All percentages $(\%)$ are presented in $\mathrm{wt} / \mathrm{wt}$ ratio.

Table 2. The list of primers used in the qPCR experiment.

\begin{tabular}{llll}
\hline Gene & Forward primer $\left(5^{\prime} \rightarrow 3^{\prime}\right)$ & Reverse primer $\left(5^{\prime} \rightarrow 3^{\prime}\right)$ & Base pair $(\mathrm{bp})$ \\
\hline Actb & TCATGAAGTGTGACGTTGACATCCGT & CCTAGAAGCATTTGCGGTGCACGATG & 285 \\
Fxr & CCAACCTGGGTTTCTACCC & CACACAGCTCATCCCCTTT & 180 \\
Cyp $7 a 1$ & TCTCCCCTTGGGACGTTTTC & AACTTCAGAGCACAGCCCAG & 176 \\
Cyp $7 b 1$ & TGGTCTGCCTGGGAATTTAGG & GCCCTATAGGCTTCCTGTCG & 223 \\
Akr $1 d 1$ & TTTCAACATCCAGCGAGGG & AGCAACTCCACATAGCGGA & 153 \\
Srebf2 & CCCTTGACTTCCTTGCTGCA & GCGTGAGTGTGGGCGAATC & 222 \\
Hmgcr & GATTCTGGCAGTCAGTGGGAA & GTTGTAGCCGCCTATGCTCC & 214 \\
Idil & GGTTCAGCTTCTAGCGGAGA & TCGCCTGGGTTACTTAATGG & 246 \\
Scarbl & TTGGCCTGTTTGTGGGATG & GGATTCGGGTGTCATGAAGG & 197 \\
Ldlr & GAGGAACTGGCGGCTGAA & GTGCTGGATGGGGAGGTCT & 239 \\
\hline
\end{tabular}

$50 \mathrm{mg}$ of the lyophilized fecal pellet was treated with $1 \mathrm{ml}$ of $75 \%(\mathrm{v} / \mathrm{v})$ ethanol and incubated at $50^{\circ} \mathrm{C}$ with gentle agitation for $2 \mathrm{~h}$ using BioShake iQ Dry Bath (Quantifoil Instruments $\mathrm{GmbH}$, Germany). The heated sample was centrifuged at $3500 \mathrm{rpm}$ for 10 minutes and $100 \mu \mathrm{l}$ of supernatant was transferred to a new tube containing $500 \mu \mathrm{l}$ of PBS for downstream assay.

Total bile acids assay kit (Colorimetric) (BioVision, USA) was used to determine the bile acid contents excreted in the mice fecal sample. The absorbance of the reaction mixture at $405 \mathrm{~nm}$ wavelength was recorded in a kinetic mode at $37^{\circ} \mathrm{C}$ for 60 minutes (once per 5 minutes) using the Infinite 200 Multimode Microplate Reader. Two time points within the linear range of the kinetic reaction were selected for slope calculation. The slope (absorbance/minute) versus bile acid amount was plotted and a linear standard curve was constructed. The bile acid contents of the fecal samples were then calculated from the standard curve and presented as a concentration of bile acid per dried feces weight $(\mu \mathrm{M} / \mathrm{g})$.

\subsection{Euthanasia}

After 8 weeks of diet manipulation, the mice were given an intraperitoneal injection with $80 \mathrm{mg} / \mathrm{kg}$ sodium pentobarbital (Sigma Aldrich, USA) to induce deep anesthesia. The anesthetized mice were then sacrificed by transcardial perfusion with $50 \mathrm{ml}$ saline at $\mathrm{pH} 7.4$ (Yeh et al., 2017). The liver and epididymal white adipose tissue were excised from the sacrificed mice's abdominal cavity and weighed. The liver tissue was then cut into smaller pieces and applied to TRIzol (Thermo Fisher Scientific, USA) or lysis buffer for RNA and protein extraction, respectively.

\subsection{Reverse transcription quantitative PCR (RT-qPCR)}

A 2-step protocol was used to amplify the RNA samples in this investigation. Total RNA from liver tissue was first DNase (Promega, USA) treated and converted to single-stranded cDNA using the Superscript III Reverse Transcriptase (Sigma Aldrich, USA) before the qPCR run. The qPCR experiment was carried out using the Quantitect SYBR Green PCR kit (Qiagen, USA) in CFX 96 TouchTM Real-Time PCR Detection System (Bio-Rad, USA). A total reaction volume of $20 \mu \mathrm{l}$ was used, which was composed of 1X SYBR Green PCR master mix, $0.5 \mu \mathrm{M}$ forward primer, $0.5 \mu \mathrm{M}$ reverse primer, and $2 \mu \mathrm{g}$ cDNA template. The protocol for the amplification was as follows: $95^{\circ} \mathrm{C}$ for 15 minutes and 35 cycles of $94^{\circ} \mathrm{C}$ for $15 \mathrm{~s}, 60^{\circ} \mathrm{C}$ for $30 \mathrm{~s}$, and $72^{\circ} \mathrm{C}$ (fluorescence) for $30 \mathrm{~s}$. A melt curve analysis comprising of the cycle $95^{\circ} \mathrm{C}$ for 1 minute, $55^{\circ} \mathrm{C}$ for 1 minute, followed by 30 -second fluorescence read at each $5{ }^{\circ} \mathrm{C}$ increment spanning from 65 to $95^{\circ} \mathrm{C}$, was also performed. The target genes and their corresponding primer sequences (Integrated DNA Technologies, IDT, Singapore) are as listed in Table 2. The qRT-PCR run was completed in a triplicate manner.

\subsection{Protein expression analysis (western blot)}

Extracted protein samples from mice liver were first separated using SDS-PAGE and then transferred to Immobilon-P polyvinylidene fluoride (PVDF) membrane. The membrane was first immunoblotted with rabbit anti-FXR antibody (Thermo-Scientific, USA) and then HRP-conjugated goat-anti-rabbit secondary antibody (Sigma Aldrich, USA). The visualization of the target protein was performed using 
Biorad ChemiDoc XRS + (Bio-Rad, USA). The protein band's intensity was computed semi-quantitatively using Image LabTM Software (Version 5.2.1, Bio-Rad, USA).

\subsection{Statistical analysis}

All the numerical data obtained from the above experiments were presented as mean \pm standard error mean (SEM). The statistical method (GraphPad Prism 7.0) used was either one-way ANOVA (Tukey's test) analysis or Student's t-test, with the significance of the results tested against the confidence level of $95 \%(p<0.05)$ and $99 \%(p<0.01)$.

\section{Results and discussion}

\subsection{Coconut milk supplementation uniquely enhance the fecal excretion of bile acid}

It was first observed that the fasting serum cholesterol level of the mice consuming coconut milk and light cream stopped increasing after the second week despite the continuous gavage (Fig. 1a). This phenomenon prompted the hypothesis that the mice might have developed a countermeasure to balance the cholesterol elevating effect introduced by the fat loads. One possible mechanism is through the reverse cholesterol transport route, where excess plasma cholesterol is delivered to the liver and catabolized into bile acid. This product is then either recycled back to the alimentary tract or excreted from the body through the feces. Fecal bile excretion can thus be used as an indicator of cholesterol clearance from the in vivo subjects. As expected, the fecal bile concentration of the coconut milk group had increased significantly by 1.68 -fold, from the basal level of $33.5 \mu \mathrm{M} / \mathrm{g}$ to $56.4 \mu \mathrm{M} / \mathrm{g}$ during the 8 th week as compared to water control (Fig. 1b). Intriguingly, though the coconut milk and light cream groups shared similar serum cholesterol progression throughout the study, the fecal bile acid content of the latter group did not change significantly after the gavage (Fig. 1b). This suggests that the light cream group had adopted an entirely different homeostatic strategy to stabilize the increase in serum cholesterol levels.

The ability of a dietary component to enhance fecal bile excretion is largely considered to be beneficial due to the supposedly cholesterol-lowering effect. For example, a Lactobacillus species was shown to be hypocholesterolemic by inducing the expression of Cyp7a1 in the liver of C57BL/6 mice, which subsequently enhanced the fecal bile acid secretion (Jeun et al., 2010). Nonetheless, despite the prominent effect of coconut milk on stimulating mice fecal bile acid excretion, the serum cholesterol level of the gavaged mice remained significantly higher after 8 weeks. Coincidentally, the administration of amaranth oil in hamsters fed with high fat and high cholesterol diet also stimulated the fecal bile acid level but had no positive implication on the blood cholesterol levels. The authors argued that amaranth oil and its main component, squalene, promote cholesterol synthesis in the hamster liver. The excessively produced cholesterol was then incorporated into bile acid to be expelled through feces as a compensatory mechanism (de Castro et al., 2013). Likewise, we speculated that the bile acid synthesis and excretion process could be used by the mice liver as a homeostatic measure to counter-balance the cholesterol elevating effect of coconut milk.

\subsection{Mice supplemented with coconut milk but not light cream halted the serum cholesterol increase through Fxr modulation}

To investigate whether bile metabolism is truly involved in the response to coconut milk intervention, the hepatic expression of four bile acid metabolism genes in the mice subject were analyzed. Consistently, the bile acid synthetic genes-Cyp7al, Cyp7b1, and Akrld1-were elevated in the liver of coconut-milk-fed mice, in conjunction with a significant down-regulation of the $F x r$ mRNA (Fig. 1c). Likewise, the Fxr protein level of the coconut milk group was also downregulated significantly (Fig. 1d). This shows that the increased bile acid excretion in the coconut milk group is modulated through the suppression of Fxr. Such changes were not observed in the light cream group, which further validated our earlier hypothesis.

The common ligands reported for Fxr are bile acids, synthetic steroidal and non-steroidal compounds, while fatty acids are not traditionally recognized as the ligand of this receptor. Nevertheless, it was shown that polyunsaturated fatty acid (PUFA) can bind the receptor and antagonized Fxr activation by CDCA in HepG2 cells. The binding also leads to differential regulation of multiple Fxr downstream targets such as $A B C B 11$ and kininogen $(K N G)$ (Zhao et al., 2004). Two medium chain length fatty acids (MCFAs), namely capric (C10:0) and caprylic (C8:0) acid, were found to promote fecal bile acid secretion through the stimulation of Cyp7a1 activity in C57BL/6J mice liver (Xu et al., 2013; Liu et al., 2017). In another independent study, the addition of capric and caprylic acid to the cholesterol-rich diet given to $\mathrm{C} 57 \mathrm{BL} / 6 \mathrm{~J}$ mice resulted in high serum triglycerides level and increased fecal bile content (Li et al., 2018). Interestingly, Li et al. (2018) proposed a different conclusion as they discovered the two MCFAs increased fecal bile acid through down-regulation of fatty acid-binding protein (Fabp6), a binding protein essential for reabsorption of bile acid from the small intestine. Since both Cyp7a1 and Fabp6 are directly regulated by Fxr, it is reasonable to postulate that the MCFAs may act on these effectors through it.

Notably, both the capric and caprylic acids used in the above studies are present in the commercial coconut milk used here (Tab. 1B). Besides, it was shown that the downregulation of Fxr was accompanied by a significant increase in Cyp $7 a 1$ expression after coconut milk intervention, which correlated well with the increase in fecal bile acid. However, the physiological change observed may not be the result of a singular factor but a coordinated function of multiple bile effectors in synthesis, transport, and circulation. Further experiments are required to clarify whether coconut milk influence on Fxr would also be relayed to other downstream bile effectors beside Cyp7a1.

\subsection{Coconut milk significantly up-regulated the fasting serum high-density lipoprotein cholesterol (HDL-C) level in C57BL/6 mice but did not impact the total cholesterol to HDL-cholesterol (HDL-C) ratio}

Though the serum cholesterol level of coconut milk and light cream groups progressed similarly, the two fat compounds 
(a)

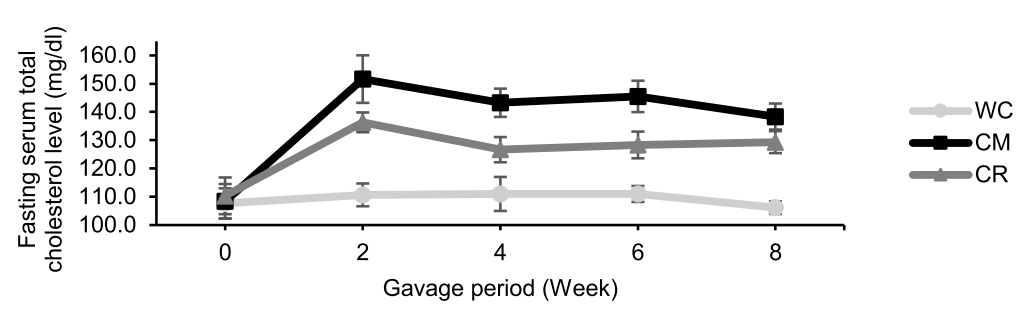

(b)

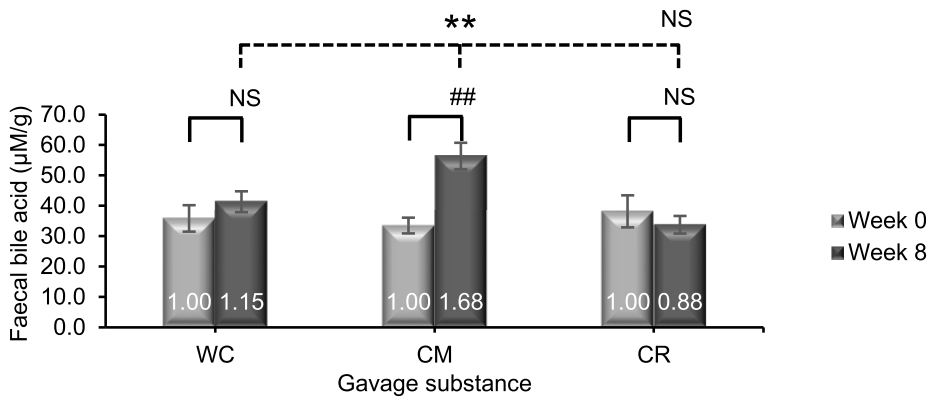

(c)

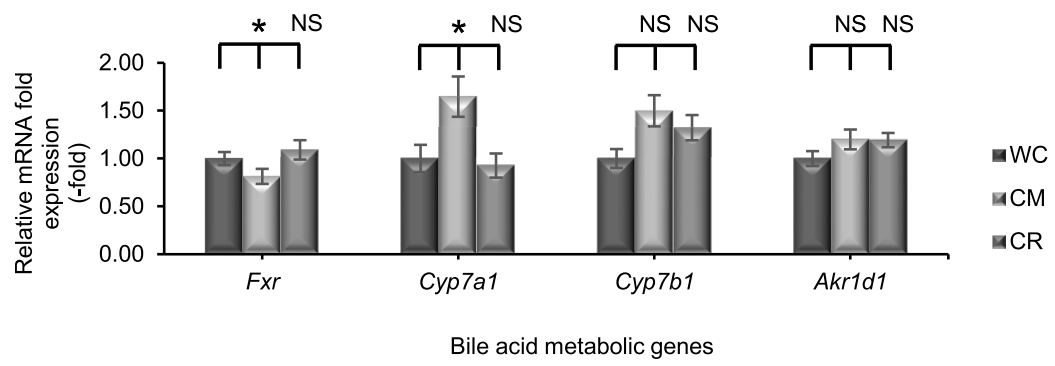

(d)
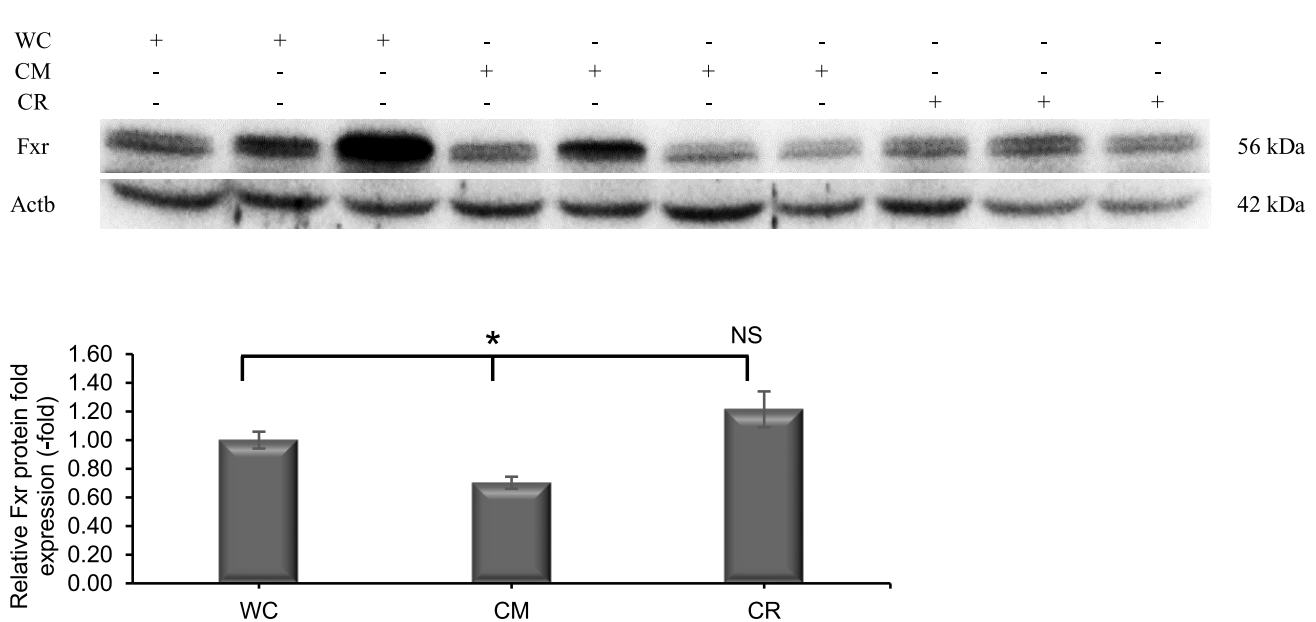

Fig. 1. (a) The fasting serum total cholesterol level of the mice from week 0 to week 8 ; (b) A comparison between fecal bile acid of the mice before (week 0) and after (week 8) the gavage. The data label at the base of each bar represents fold expression relative to the respective week 0 reading (which is arbitrarily set as 1.00-fold); (c) The expression of bile metabolic genes found in C57BL/6 mice liver tissue following the gavage experiment. Note: * representing significance above CM protein level in (d) is missing; (d) The representative Western blot image of Fxr and Actb proteins in mice liver tissue. The mRNA (C) and protein (D) expression levels were determined by normalization to Actb expression and relative to WC (1.00-fold). WC: water control group $(n=6)$; CM: coconut milk group $(n=8)$; and CR: light cream group ( $n=6)$. Two-tailed paired sample t-test (solid line) and one-way ANOVA Tukey's test (dotted line) were performed on the result. ${ }^{*} p<0.05$ and ${ }^{* *} p<0.01$ signifies a statistically significant alteration from WC control; ${ }^{\# \#} p<0.01$ signifies statistical significant change from week 0 control; while NS represents non-significance. 
(a)
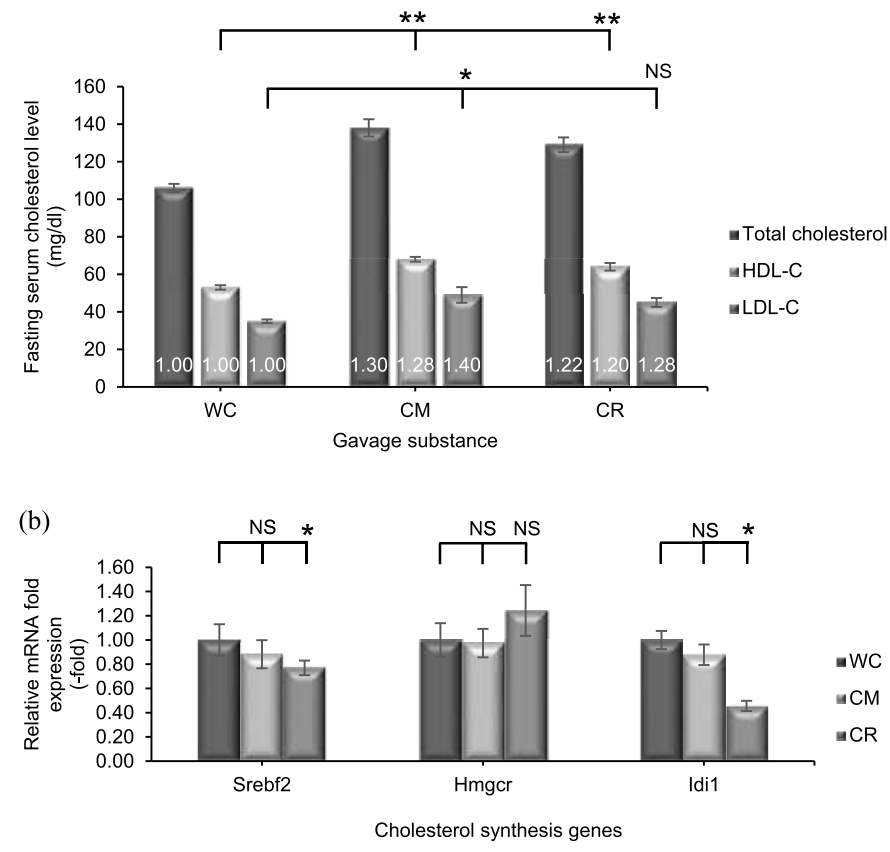

(c)

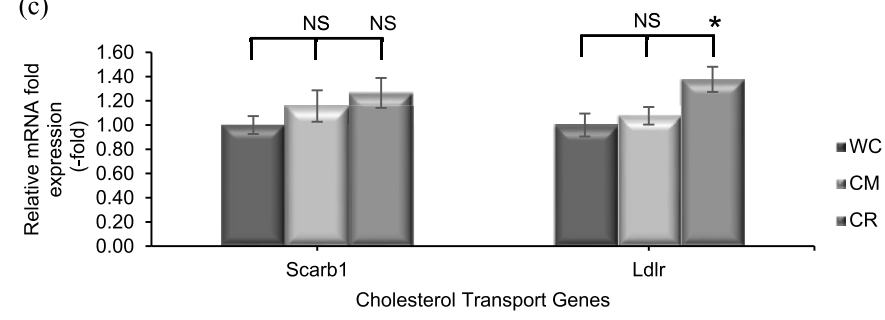

Fig. 2. (a) The fasting serum total cholesterol, HDL-C, and LDL-C concentration on the 8 th week. The data label at the base of each bar represents fold expression relative to WC (which is arbitrarily set as 1.00 -fold). The expression of (b) cholesterol synthesis genes, and (c) cholesterol uptake genes found in $\mathrm{C} 57 \mathrm{BL} / 6$ mice liver tissue following the gavage experiment. The mRNA expression levels were determined by normalization to $A c t b$ and relative to WC (1.00-fold). ${ }^{*} p<0.05$ and ${ }^{* *} p<0.01$ signifies a statistically significant alteration from WC control; while NS represents non-significance.

might exert different effects over the serum cholesterol profile. Unfortunately, though further analysis showed that gavage feeding of coconut milk significantly up-regulated the HDL-C level after 8 weeks, this effect was mirrored by light cream feeding (Fig. 2a). The elevation of HDL-C was not found to improve the total cholesterol to HDL ratio either, as all three groups yielded an equivalent ratio value of $\sim 2.00$-fold. In this regard, coconut milk supplementation showed no distinct advantage over light cream gavage.

The elevation in plasma cholesterol could be either caused by increased biosynthesis or decreased uptake by the liver. Thus, we next determine whether the serum cholesterol elevation of the two fat-fed groups was caused by an anomaly in cholesterol synthesis (Srebf2, Hmgcr, and Idi1) (Fig. 2b) or cholesterol uptake (Scarb1, and Ldlr) (Fig. 2c). Intriguingly, the coconut milk group showed no significant alteration in the hepatic mRNA expression of these five genes after 8 weeks. Meanwhile, light cream was found to significantly downregulated $S r e b f 2$ and $I d i l$ and induced $L d l r$ expression in mice liver after the gavage. This suggests that the light cream group might have stabilized the serum cholesterol level through a decrease in cholesterol synthesis (Srebf2 and Idi1) and enhanced cholesterol uptake ( $L d l r)$ - a completely different approach from the coconut milk group, which had its bile excretion enhanced. More concrete evidence would be needed to confirm this hypothesis. Based on these mRNA expressions alone, this study is unable to pinpoint the exact mechanism in which coconut milk and light cream have promoted the serum cholesterol level. The gavage substances might have acted post-transcriptionally or targeted other lipid metabolism genes.

In this study, both gavage substances used are rich in saturated fatty acid (e.g. lauric acid, myristic acid, palmitic acid, etc.), which is long regarded as hypercholesterolemic (Fernandez and West, 2005; Siri-Tarino et al., 2015). But it has now been proven that not all saturated fatty acids impact serum cholesterol profiles the same way. A meta-analysis performed by Mensink (2016) which reviewed 84 diet trials (2009-2013) concluded that the increased consumption of lauric, myristic, or palmitic acids concomitantly raised serum total, HDL, and LDL cholesterol level. Among the three, only lauric acid was specifically found to significantly improve the total cholesterol to HDL cholesterol ratio. Even so, mice supplemented with coconut milk (MCFA-rich) for 8 weeks yielded an analogous serum cholesterol profile to that of light cream (LCFA-rich) in this study, despite the different fatty acid composition. The effect of individual fatty acid (in this case, lauric acid) may be mitigated when consumed as a compound with other fatty acids, since coconut milk also contains a moderate level of LCFAs.

\subsection{The gavage of both fat produced minimal impact on serum triglycerides level}

Both coconut milk and light cream are lipid-rich products containing a high amount of saturated fatty acid. Other than the serum cholesterol level, this study also investigates how the supplementation might affect the serum triglycerides level in mice. The timeline graph displayed in Figure $3 \mathrm{a}$ shows that both coconut milk and light cream groups generally exhibited a higher rise in fasting serum triglycerides level as compared to the water control group throughout the feeding. Nevertheless, ANOVA Tukey's test showed that there was no statistical difference found between the serum triglycerides level of the three gavage groups on the 8th week (Fig. 3b). This depicts that the induction in serum triglycerides level could be age-related rather than due to the difference in gavage substances.

Such observation is consistent with past findings. In a highfat diet study, the plasma triglycerides level of C57BL/6 mice fed with a high saturated fat diet $[21 \%(\mathrm{wt} / \mathrm{wt})]$ for 8 weeks was found to be constant to the mice fed low-fat chow diet (EscolaGil et al., 2011). Moreover, it was shown that female Apoe-/C57BL/6 mice with similar high fat content diet had plasma triglycerides level reduced significantly as compared to chowfed control after 8 weeks of feeding (Kolbus et al., 2010). In these experiments, the amount of fat given to the mice subjects within the same time frame was higher, and yet it failed to 


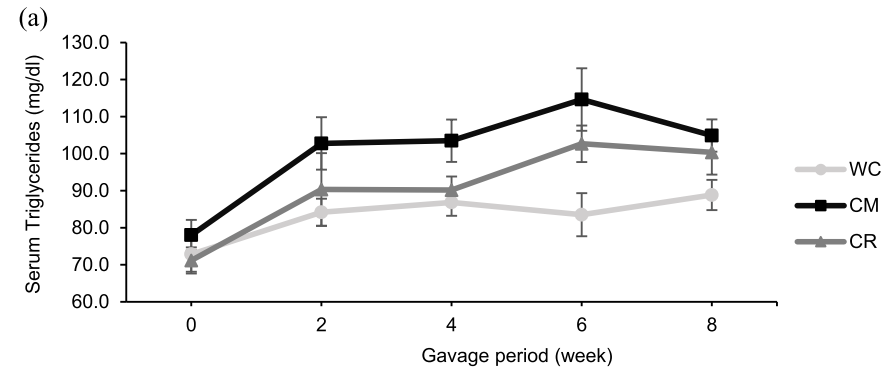

(b)

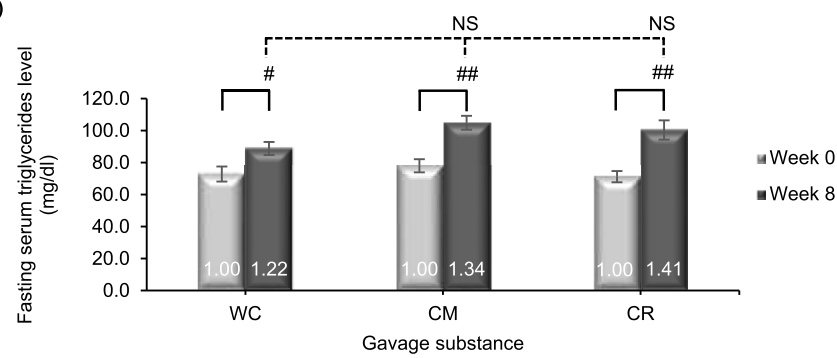

Fig. 3. (a) The fasting serum triglycerides level of the mice from week 0 to week 8; (b) A comparison between fasting serum triglycerides levels before (week 0) and after (week 8) the gavage feeding test. The data label at the base of each bar represents the fold expression relative to the respective week 0 reading (which is arbitrarily set as 1.00 -fold). WC: water control group $(n=6) ; \mathrm{CM}$ : coconut milk group $(n=8)$; and CR: light cream group $(n=6)$. Two-tailed paired sample ttest (solid line) and one-way ANOVA Tukey's test (dotted line) were performed on the result. ${ }^{\#} p<0.05$ and ${ }^{\# \#} p<0.01$ signify a statistically significant alteration from week 0 control; while NS represents nonsignificance.

induce the plasma triglycerides level in the rodents. Hence, it is plausible that coconut milk and light cream supplemented here did not promote a significant change in the fasting serum triglycerides level of the wild type C57BL/6 mice. Gao et al. (2010) investigated the underlying cause of this phenomenon and proposed that mice plasma triglycerides level was unresponsive to high-fat feeding due to the differential expression of Mttp gene in the mice liver as compared to other more triglycerides-sensitive species, such as Syrian golden hamster.

\section{Conclusion}

The main objective of this study is to identify the potential molecular impact of coconut milk, a popular food ingredient in South East Asia, toward lipid metabolism. It is demonstrated here that coconut milk can modulate the Fxr expression in liver and promote cholesterol clearance through the bile synthesis pathway. On the other hand, this study also shows although coconut milk is hypercholesterolemic, it does not raise the total cholesterol to HDL cholesterol ratio. Nevertheless, the findings here show that mice consuming different substances could undergo different molecular responses to resist the rise in serum cholesterol level. Here we show that the constituents in coconut milk, but not light cream, is able to interact with Fxr and in turn regulates its downstream effectors. Further research using the individual constituents of coconut milk may be required to unravel this unique bile stimulating effect.
Acknowledgment. This project was funded by the Universiti Tunku Abdul Rahman Research Grant (UTARRF 6200/C86, $6200 / C B 5)$. We would like to channel our special gratitude to Professor Huey Jen Tsay for her willingness to provide the facility and technical support when the project (in vivo) was carried out at National Yang-Ming University, Taiwan.

Conflicts of interest. The authors declare that they have no conflict of interest.

\section{References}

Amarasiri WALD, Dissanayake AS. 2006. Coconut fats. Ceylon Med $J$ 51(2): 47-51.

Arunima S, Rajamohan T. 2012. Virgin coconut oil improves hepatic lipid metabolism in rats - Compared with copra oil, olive oil and sunflower oil. Indian J Exp Biol 50: 802-809.

Boué S, Fortgang I, Levy RJ, et al. 2016. A novel gastrointestinal microbiome modulator from soy pods reduces absorption of dietary fat in mice. Obesity 24(1): 87-95.

Charach G, Rabinovich A, Argov O, Weintraub M, Rabinovich P. 2012. The role of bile acid excretion in atherosclerotic coronary artery disease. Int J Vasc Med 949672.

Chiang JYL. 2009. Bile acids: regulation of synthesis. J Lipid Res 50 (10): 1955-1966.

de Castro LÍA, Soares RAM, Saldiva PHN, et al. 2013. Amaranth oil increased fecal excretion of bile acid but had no effect in reducing plasma cholesterol in hamsters. Lipids 48(6): 609-618.

DiBello JR, McGarvey ST, Kraft P, et al. 2009. Dietary patterns are associated with metabolic syndrome in adult Samoans. J Nutr 139 (10): 1933-1943.

Enig MG. 1996. Health and nutritional benefits from coconut oil: an important functional food for the 21st century. In: AVOC Lauric Oils Symposium. The Western A. Price Foundation: Ho Chih Min.

Escola-Gil JC, Llaverias G, Julve J, Jauhiainen M, Mendez-Gonzalez J, Blanco-Vaca F. 2011. The cholesterol content of Western diets plays a major role in the paradoxical increase in high-density lipoprotein cholesterol and upregulates the macrophage reverse cholesterol transport pathway. Arterioscler Thromb Vasc Biol 31 (11): 2493-2499.

Eyres L, Eyres MF, Chisholm A, Brown RC. 2016. Coconut oil consumption and cardiovascular risk factors in humans. Nutr Rev 74(4):267-280.

Fernandez ML, West KL. 2005. Mechanisms by which dietary fatty acids modulate plasma lipids. J Nutr 135(9):2075-2078.

Foale M. 2003. The wonder food. In: The coconut odyssey. Canberra: Australia Centre for International Agricultural Research, pp. 121-132.

Gao S, He L, Ding Y, Liu G. 2010. Mechanisms underlying different responses of plasma triglyceride to high-fat diets in hamsters and mice: Roles of hepatic MTP and triglyceride secretion. Biochem Biophys Res Commun 398(4): 619-626.

Høstmark AT, Lystad E, Haug A, Eilertsen E. 1989. Plasma lipids, lipoproteins, and fecal excretion of neutral sterols and bile acids in rats fed various high fat diets or a low fat/high sucrose diet. J Nutr 119(3): 356-363.

Jakulj L, van Dijk TH, de Boer JF, et al. 2016. Transintestinal cholesterol transport is active in mice and humans and controls ezetimibe-induced fecal neutral sterol excretion. Cell Metab 24 (6): 783-794.

Jeun J, Kim S, Cho S-Y, et al. 2010. Hypocholesterolemic effects of Lactobacillus plantarum KCTC3928 by increased bile acid excretion in C57BL/6 mice. Nutrition 26(3): 321-330. 
Jost R. 2007. Milk and dairy products. In: Ullmann's Encyclopedia of Industrial Chemistry. Weinheim: Wiley-VCH Verlag $\mathrm{GmbH} \&$ Co. KGaA, 2012, 318 p.

Kolbus D, Ramos OH, Berg KE, et al. 2010. CD8+ T cell activation predominate early immune responses to hypercholesterolemia in Apoe $\left({ }^{-} /\right)$mice. BMC Immunol 11: 58.

Li H, Liu Y, Zhang X, et al. 2018. Medium-chain fatty acids decrease serum cholesterol via reduction of intestinal bile acid reabsorption in C57BL/6J mice. Nutr Metab 15(37): 1-12.

Lipoeto NI, Agus Z, Oenzil F, Wahlqvist M, Wattanapenpaiboon N. 2004. Dietary intake and the risk of coronary heart disease among the coconut-consuming Minangkabau in West Sumatra, Indonesia. Asia Pac J Clin Nutr 13(4): 377-384.

Liu Y, Zhang Y, Zhang X, Xu Q, Yang X, Xue C. 2017. Medium-chain fatty acids reduce serum cholesterol by regulating the metabolism of bile acid in C57BL/6J mice. Food Funct 8(1): 291-298.

Mangiapane EH, McAteer MA, Benson GM, White DA, Salter AM. 1999. Modulation of the regression of atherosclerosis in the hamster by dietary lipids: comparison of coconut oil and olive oil. Br J Nutr 82(05): 401-409.

Mensink RP. 2016. Effects of saturated fatty acids on serum lipids and lipoproteins: a systematic review and regression analysis. Geneva: World Health Organization.

Ramesha CS, Paul R, Ganguly J. 1980. Effect of dietary unsaturated oils on the biosynthesis of cholesterol, and on biliary and fecal excretion of cholesterol and bile acids in rats. J Nutr 110(11): 2149-2158.

Ramsden CE, Zamora D, Majchrzak-Hong S, et al. 2016. Reevaluation of the traditional diet-heart hypothesis: analysis of recovered data from Minnesota Coronary Experiment (1968-73). BMJ 353: i1246.
Sim JS, Kitts WD, Bragg DB. 1980. Influence of dietary oil, cholesterol, and soysterols on the fecal neutral and Acidic steroid excretion in laying hens. Poult Sci 59: 325-327.

Siri-Tarino PW, Chiu S, Bergeron N, Krauss RM. 2015. Saturated fats versus polyunsaturated fats versus carbohydrates for cardiovascular disease prevention and treatment. Annu Rev Nutr 35(1): 517-543.

Soma M, Manku MS, Horrobin DF. 1985. The effects of hydrogenated coconut oil, safflower oil, and evening primrose oil on development of hypertension and sodium handling in spontaneously hypertensive rats. Can J Physiol Pharmacol 63(4): 325-330.

Tangsuphoom N. Properties and structure of coconut milk emulsions. Thesis, The Pennsylvania State University, 2008.

Vallim T, Tarling EJ, Edwards PA. 2013. Pleiotropic roles of bile acids in metabolism. Cell Metab 17: 657-669.

Vermeir L. 2010. Formulation and characterization aspects of low fat whipping cream by water/oil/water technology. Thesis, Katholieke Universiteit Leuven.

$\mathrm{Xu}$ Q, Xue C, Zhang Y, et al. 2013. Medium-chain fatty acids enhanced the excretion of fecal cholesterol and cholic acid in C57BL/6J mice fed a cholesterol-rich Diet. Biosci Biotechnol Biochem 77(7): 1390-1396.

Yeh CW, Liu HK, Lin LC, et al. 2017. Xuefu Zhuyu decoction ameliorates obesity, hepatic steatosis, neuroinflammation, amyloid deposition and cognition impairment in metabolically stressed APPswe/PS1dE9 mice. J Ethnopharmacol 209: 50-61.

Zhao A, Yu J, Lew J-L, Huang L, Wright SD, Cui J. 2004. Polyunsaturated fatty acids sre FXR ligands and differentially regulate expression of FXR targets. DNA Cell Biol 23(8): $519-526$.

Cite this article as: Wong HK, Choo QC, Chew CH. 2020. Coconut milk gavage enhanced fecal bile excretion by modulating hepatic Fxr expression but failed to improve fasting serum cholesterol profile in C57BL/6 mice. OCL 27: 50 . 